\section{Fascinerende om øyebevegelser}

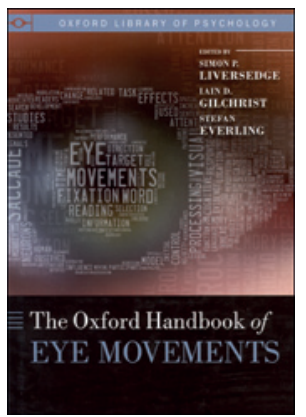

Simon Liversedge, lain Gilchrist,

Stefan Everling, red.

The Oxford handbook of eye movements

1027 s, tab, ill. Oxford: Oxford University

Press, 2011. Pris GBP 95

ISBN 978-0-19-953978-9

Hvordan og hvorfor vi beveger øynene, og hvordan de påvirkes av våre aktiviteter og tankevirksomhet, er temaet for denne omfattende boken. Teknologiutviklingen, som i dag muliggjør nøyaktige registreringer av øyebevegelser, har i stor grad bidratt til at forskere bruker øyebevegelser til å undersøke den visuelle og kognitive bearbeidingen av en rekke av menneskets aktiviteter som lesing, språk, problemløsning og psykologiske prosesser, sosial oppmerksomhet og interpersonal kommunikasjon.

Gjennom over 1000 sider og 54 kapitler gir 91 forfattere en oversikt over forskningsfeltet øyebevegelser. Boken er delt i sju deler. Første og andre del er historikk om forskningen på dette området og omtaler øyebevegelser hos forskjellige dyrearter og beskriver de forskjellige typene øyebevegelser, anatomien og den nevrale mekanismen ved det okulomotoriske systemet. Tredje del handler om oppmerksomhet og øyebevegelser, neste del om visuell kognitiv prosessering. I en egen del viser forfatterne utviklingen av øyebevegelser hos mennesker, og i de to siste delene gir de informasjon om okulomotorisk kontroll ved lesing og sammenhengen mellom språk og øyebevegelser.

Forfatterne er spesialister på sine felt, og de skriver med autoritet, kunnskap og god formidlingsevne. Til tross for mange forfattere er hvert kapittel bygd opp etter samme mal, noe som gjør boken enhetlig. Hvert kapittel avsluttes med en innholdsrik og oppdatert referanseliste. Antall illustrasjoner er passende. Skriften er imidlertid altfor liten, sannsynligvis med tanke på å unngå å gjøre boken ytterligere voluminøs.

Alle med interesse for øyebevegelser vil finne mye spennende stoff om samspillet mellom øyebevegelser og hjernen, og om hvordan hukommelse, språk, alder, hverdagsaktiviteter og forventninger påvirker øyebevegelsene. For eksempel sammenliknes sjakkspillerens visuelle søking på brettet med radiologen som leter etter patologiske funn.

Når det gjelder hukommelsen, gir øyemotilitetsregistrering nyttig tilleggsinformasjon som ikke kan måles med andre metoder. Vi lærer at de reflektoriske øyebevegelsene, som fiksasjon, visuelt guidede sakkader og følgebevegelser, utvikles i barndommen, mens læringen av den viljestyrte okulomotorikken som antisakkader og hukommelsesledede sakkader foregår helt til voksen alder. Vi får også kjennskap til psykolingvistikk, hvordan øyemotiliteten endres når et enkelt ord eller syntaks manipuleres, og hvordan talt språk endrer mønsteret av øyebevegelsene.

Forfatterne formidler eksperimentell laboratorievitenskap, og boken er et utmerket oppslagsverk først og fremst for psykologer og eksperimentelle basalforskere. Den er ikke klinisk innrettet, praktiserende leger er ikke målgruppen. Men det er fascinerende lesing for alle som er interessert i den finstemte orkestreringen som øyebevegelser representerer.

\section{Emilia Kerty}

Nevrologisk avdeling

Oslo universitetssykehus, Rikshospitalet

\section{Oppslagsverk i geriatrisk kirurgi}

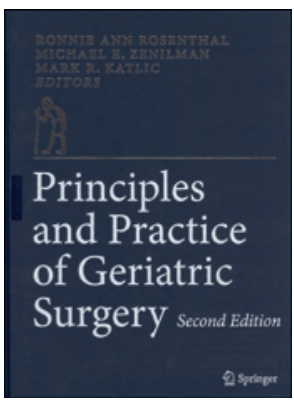

Ronnie Ann Rosenthal, Michael E. Zenilman, Mark R. Katlic, red.

Principles and practice of geriatric surgery 2. utg. 1387 s, tab, ill. Heidelberg: Springer, 2011. Pris EUR 170

ISBN 978-1-4419-6998-9

I forordet til førsteutgaven i 2001 het det at formålet ikke var å beskrive en ny spesialitet i kirurgi, men at boken skulle være en lærebok for alle som driver med medisinsk og kirurgisk behandling av eldre - og det gjelder nå alle, bortsett fra barnekirurgene. Boken inneholder således temaer relatert til hele det kirurgiske fagfeltet, inkludert transplantasjon, traumatologi, nevrokirurgi, øre-nese-hals, ortopedi og plastikkirurgi. Over 100 amerikanske forfattere bidrar til 98 kapitler og kommentarer i det som fremstår mer som et oppslagsverk enn en lærebok. Flere kjente fagpersoner er representert.

Bidragsyterne begynner med fysiologi og aldringsprosesser og tar opp sosiale og strukturelle aspekter rundt eldre og tilpasning og begrensninger i samfunnet. Selv om en del er preget av amerikanske forhold, er likevel mye av stoffet allment nyttig. Etikk og vurdering rundt livets sluttfase gir et helhetlig perspektiv, selv om det ikke finnes «fasitsvar».

Flere av kapitlene innledes med illustrerende kasuistikker. De fleste kapitlene er godt utstyrt med referanser og jevnt over god bruk av illustrasjoner og tabeller. Innbindingen er god, og papiret er solid. Det er mye bra stoff mellom permene.

En kritisk merknad kan være at mye av stoffet finnes i alle lærebøker i kirurgi. Jeg savner derfor enkelte steder en mer penetrerende tilnærming og spesifikt søkelys på det geriatriske aspektet. En del påstander som «well tolerated» og «low mortality» hos eldre med referanser til serier fra Memorial Sloan-Kettering Cancer Center, Mayo Clinic og Johns Hopkins Hospital savner en bredere diskusjonsflate. Vel er nordmenn født med ski på beina, men ikke alle går like fort som Petter Northug og Marit Bjørgen. Slik vil også de fleste sykehus operere (bokstavelig talt) rundt «medianen». Eldre kan tåle en gitt operasjon, men ikke komplikasjonene, og den totale risikovurderingen blir derfor annerledes.

De fleste illustrasjonene er i svart-hvitt. Noe strengere redigering kunne nok kondensert innholdet betydelig. Enkelte redaksjonelle glipper synes også å foreligge, som at Trunkeys kommentar til skader hos eldre er kommet mellom kapitlet om medikamentbruk hos eldre og kapitlet om vanlige perioperative komplikasjoner hos eldre. Kommentaren burde stått etter kapitlet hvor man spesifikt omtaler behandling av skader hos eldre.

Dette er ikke en bok som man leser fra perm til perm, men som totalt sett er informerende, og hvor enkeltkapitler vil være av stor nytte til fordypning og/eller oppfriskning. Boken bør være tilgjengelig på alle kirurgiske avdelinger.

\section{Kjetil Søreide}

Kirurgisk avdeling

Stavanger universitetssjukehus 